Article

\title{
Synthesis and Conformational Analysis of Fluorinated Uridine Analogues Provide Insight into a Neighbouring-Group Participation Mechanism
}

\author{
Freideriki Michailidou ${ }^{1,2}$, Tomas Leb1 ${ }^{1}$, Alexandra M. Z. Slawin ${ }^{1}{ }^{10}$, \\ Sunil Vishnuprasadji Sharma ${ }^{1}$, Murray J. B. Brown ${ }^{2}$ and Rebecca Jane Miriam Goss ${ }^{1, *}$ \\ 1 EaStCHEM School of Chemistry, University of St Andrews, North Haugh, St Andrews, Fife KY16 9ST, UK; \\ fm59@st-andrews.ac.uk (F.M.); tl12@st-andrews.ac.uk (T.L.); amzs@st-andrews.ac.uk (A.M.Z.S.); \\ svs4@st-andrews.ac.uk (S.V.S.) \\ 2 GlaxoSmithKline, Stevenage SG1 2NY, UK; murray.j.brown@gsk.com \\ * Correspondence: rjmg@st-andrews.ac.uk
}

Received: 13 October 2020; Accepted: 15 November 2020; Published: 25 November 2020

\begin{abstract}
Fluorinated nucleoside analogues have attracted much attention as anticancer and antiviral agents and as probes for enzymatic function. However, the lack of direct synthetic methods, especially for $2^{\prime}, 3^{\prime}$-dideoxy-2', $3^{\prime}$-difluoro nucleosides, hamper their practical utility. In order to design more efficient synthetic methods, a better understanding of the conformation and mechanism of formation of these molecules is important. Herein, we report the synthesis and conformational analysis of a $2^{\prime}, 3^{\prime}$-dideoxy-2' $3^{\prime}$-difluoro and a $2^{\prime}$-deoxy-2'-fluoro uridine derivative and provide an insight into the reaction mechanism. We suggest that the transformation most likely diverges from the $S_{N} 1$ or $S_{N} 2$ pathway, but instead operates via a neighbouring-group participation mechanism.
\end{abstract}

Keywords: nucleoside; fluorine; fluorination; neighbouring-group participation; mechanism

\section{Introduction}

Fluorinated nucleosides and nucleotide analogues have attracted much attention as antiviral and anticancer drugs or mechanistic probes [1-4]. Since the development of the first fluorine-containing drug in 1957, the research in the field of fluorine chemistry has flourished, leading to noteworthy industrial applications [5]. To date, the portfolio of fluorinated drugs includes over 150 compounds, constituting $\sim 20 \%$ of all pharmaceuticals (increasing to well above $30 \%$ for recent FDA-approved drugs) [5]. Furthermore, the widely used antidepressant fluoxetine (Prozac), the antibacterial ciprofloxacin (Ciprobay) and the anti-inflammatory fluticasone are fluorine-containing drugs. A selection of the most successful organofluorine-containing blockbuster drugs, including sitagliptin (for the treatment of diabetes); sofosbuvir (hepatitis C); dolutegravir, bictegravir and efavirenz (HIV); and enzalutamide (prostate cancer), highlight the significance of fluorinated bioactive compounds $[6,7]$. Fluorinated nucleoside analogues nucleocidin 1, 5-fluorouracil 2, gemcitabine 3, LY2334737 4, sofosbuvir 5, NUC-1031 6 and RX3117 7 are shown in Scheme 1 [8,9]. Nucleocidin, a natural product and trypanosome-active antibiotic, was initially isolated from Streptomyces calvus and bears a fluorine atom at the $4^{\prime}$ position [9]. 5-Fluorouracil is an anticancer agent manufactured on an industrial scale, while gemcitabine, which contains two fluorine atoms at the $2^{\prime}$ position, is a chemotherapy medication used to treat a number of types of cancer $[8,10]$. LY2334737 was designed as a prodrug of gemcitabine, with anticipated increased bioavailability; however, it was discontinued due to its hepatic toxicity in patients [11,12]. Sofosbuvir is a medication for hepatitis C, while NUC-1031 is a $5^{\prime}$-phosphoramidate prodrug of gemcitabine $[13,14]$. RX-3117 has shown efficacy in clinical trials 
against drug-resistant tumours and has received "orphan drug designation" for pancreatic cancer from the U.S. Food and Drug Administration (FDA) and from the European Commission (EC) $[15,16]$.<smiles>N#C[C@H](O)O[C@H]1[C@@H](O)[C@@H](COS(N)(=O)=O)O[C@H]1n1cnc2c(N)ncnc21</smiles>

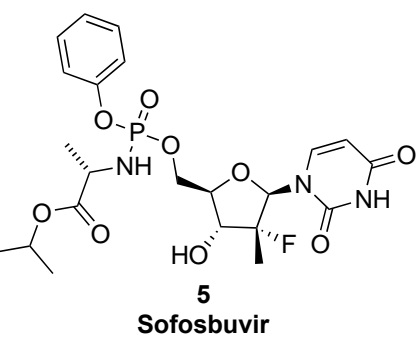





Gemcitabine

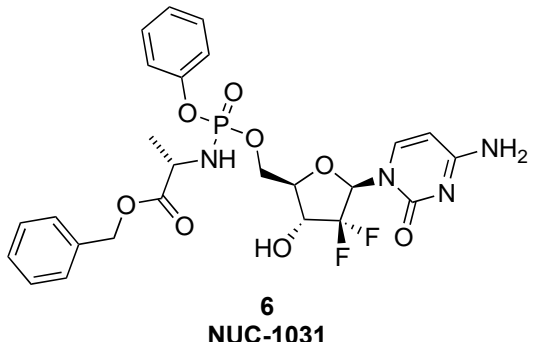

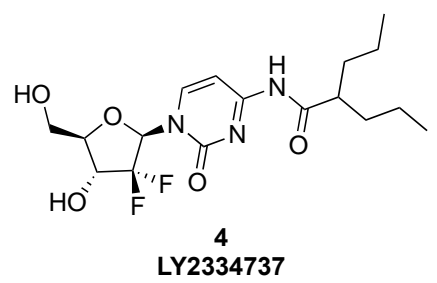

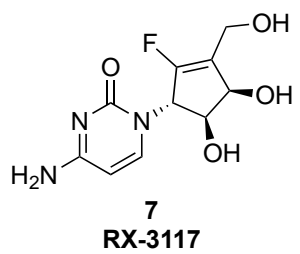

Scheme 1. Fluorine moieties present in nucleocidin, 5-fluorouracil, gemcitabine, LY2334737, sofosbuvir, NUC 1031 and RX-3117.

The unique steric and electronic properties of fluorine have led to its use in probing enzymatic mechanisms and to the C-F bond playing a very dominant role in medicinal chemistry [5,17-20]. As a close steric replacement for hydrogen, fluorine can introduce important electronic changes in a molecule with minimal steric perturbation. Fluorine is also used as a hydroxyl mimic, given its hydrogen bonding ability and the proximity of the C-F bond length (1.35 $\AA$ ) to the C-O bond length (1.43 $\AA$ ) [17]. Due to the stability of the C-F bond $\left(105.4 \mathrm{kcal} \mathrm{mol}^{-1}\right)$, replacing a hydrogen or a hydroxyl group with fluorine significantly improves the metabolic stability of the compound. Oxidative degradation of biomolecules in vivo, for example oxidation by P450 enzymes, can be prevented via the utilisation of fluorinated analogues [5,21,22]. The basicity of a molecule can also be reduced by introducing a fluorine atom in proximity to the basic group [21,22]. Notably, incorporating one or more C-F bonds within a molecule provides a means of increasing lipophilicity and improving bioavailability as well as promoting hydrophobic interactions between the drug and binding sites on receptors or enzymes [18].

The design of new fluorinated nucleoside analogues and the need for their syntheses have driven the research in the field of fluorine nucleoside chemistry [23]. Owing to the aforementioned unique properties of fluorine, fluorinated nucleoside analogues have found applications as chemotherapeutics in the clinic, and in general as drugs and mechanistic probes. Replacement of one or more hydroxyls of the nucleoside ring with an almost isosteric C-F bond impacts the electronics and the hydrophobicity of the compounds as well as reducing their ability to hydrogen bond. Furthermore $2^{\prime}, 3^{\prime}$-dideoxy nucleosides cannot be extended within a natural nucleic acid polymer, and as well as inhibiting enzymes such as reverse transcriptase, they can be used to terminate replication or transcription/reverse transcription of such a polymer [1]. Fluorination at $\mathrm{C}^{\prime}$ ' has been long been known to both promote furanose conformation change and improve metabolic stability [24], whilst replacement of the $3^{\prime}$ and $5^{\prime}$ alcohols prevents chain extension [25]. Such modified nucleic acids can also inhibit enzymes such as DNA or RNA polymerases, reverse transcriptases and nucleoside phosphorylases that are essential for cancer cell growth and viral replication [26,27].

However, introducing a fluorine atom into a sugar moiety in nucleosides can be challenging. For the synthesis of $2^{\prime}, 3^{\prime}$-dideoxy-2', $3^{\prime}$-difluoro nucleosides, the potential for hydroxyl elimination rather than substitution, due to the poor nucleophilicity yet considerable basicity of fluoride, adds to the synthetic challenge. A recent four-step sequence [28] giving access to series of nucleoside analogues, 
though notably no ribose-fluorinated analogues, was reported using a "ribose-last" approach whilst we were preparing this manuscript for publication; in a complementary study, we set out to explore a direct approach to ribose-fluorinated $5^{\prime}$-O-protected uridine analogues to gain greater insight into their conformations and thereby the mechanisms by which they might be formed.

It has been reported that electronegative substituents at the $\mathrm{C}^{\prime}$ of adenosines favour the $\mathrm{C}^{\prime}$ endo-conformation, placing the hydroxyl diaxial to an acidic proton and promoting E2 elimination. However, bulky substituents at $\mathrm{C}^{\prime}$ and $\mathrm{C}^{\prime}$ mostly favour a $\mathrm{C}^{\prime}$ endo-conformation, preventing elimination $[29,30]$. Rationalising in this paper that a large protecting group could be used to promote substitution rather than elimination, we explored the potential for the direct nucleophilic fluorination of the $2^{\prime}$ and $3^{\prime}$ positions in $5^{\prime}-O$-protected uridine analogues. We further performed structural and conformational analysis of the derived uridine analogues and provided insight into the reaction mechanism.

\section{Results}

\subsection{Synthesis of Fluorinated Nucleoside Analogues}

Unlike previously reported strategies that involve a two-step insertion of fluorine in the $2^{\prime}$ and $3^{\prime}$ positions of the nucleoside for the synthesis of the 2,3-dideoxy-2,3-difluoro sugars followed by base condensation [31,32], we aimed at the direct functionalisation of the corresponding positions in $5^{\prime}$-O-protected uridine analogues. Whilst our initial attempts to functionalise the $2^{\prime}$ and $3^{\prime}$ hydroxyl groups of 5'-O-carboxybenzyl (Cbz) and of 5'-O-benzoyl (Bz) uridine derivatives using fluorinating reagents diethylaminosulfur trifluoride (DAST) and Deoxo-Fluor proved unsuccessful, we attempted the utilisation of analogues protected by benzyl $(\mathrm{Bn})$ groups. Bn groups are often used in nucleoside and carbohydrate chemistry as being compatible with a wide range of reaction conditions, as they are relatively stable to both acid and base [33], and would potentially be stable to the demanding reaction conditions and long reaction times required for fluorination. Acetonide 9, which was synthesised using reported protocols [34], was further subjected to treatment with benzyl bromide and sodium hydride to yield compound $\mathbf{1 0}$ in a 73\% yield. Standard deprotection using aqueous trifluoroacetic acid (TFA) removed the acetonide function and yielded 11, the starting material for the fluorination reaction. Treatment of $\mathbf{1 1}$ with Deoxo-Fluor (10 equiv.) in toluene at RT for $48 \mathrm{~h}$ led to compounds $\mathbf{1 2}$ and 13 (Scheme 2). The desired monofluorinated product 12 was obtained in a 53\% yield after flash column chromatography. The ${ }^{19} \mathrm{~F}$ NMR revealed a singlet at $-185 \mathrm{ppm}$, while the proton coupled spectrum revealed a ddd with the expected coupling constants: ${ }^{2} J_{\mathrm{F}-\mathrm{H} 2^{\prime}} 48.8 \mathrm{~Hz},{ }^{3} J_{\mathrm{F}-\mathrm{H} 1^{\prime}} 20.9 \mathrm{~Hz},{ }^{3} J_{\mathrm{F}-\mathrm{H} 3^{\prime}}$ $9.9 \mathrm{~Hz}$. The position of the fluorine at the $\mathrm{C} 2{ }^{\prime}$ was verified by ${ }^{1} \mathrm{H} N M R,{ }^{13} \mathrm{C}$ NMR and ${ }^{1} \mathrm{H}\{\mathrm{F}\} \mathrm{NMR}$ (SI, Figures S1-S4). The apparent singlet at $5.92 \mathrm{ppm}$ in the fluorine-decoupled ${ }^{1} \mathrm{H}$ NMR corresponds to the $\mathrm{H} 1^{\prime}$, and splits into a doublet with a coupling constant of $20.9 \mathrm{~Hz}$ in the fluorine-coupled spectrum. This coupling constant is representative of ${ }^{3} J$ proton-fluorine interaction. The ${ }^{19} \mathrm{~F}\{\mathrm{H}\} \mathrm{NMR}$ of the compound assigned as the difluorinated molecule 13, revealed the two doublets at -192 and $-208 \mathrm{ppm}$ $\left({ }^{3} \mathrm{~J}=14.3 \mathrm{~Hz}\right)$. Further details of NMR analysis are provided in the SI (Figures S1-S4). 


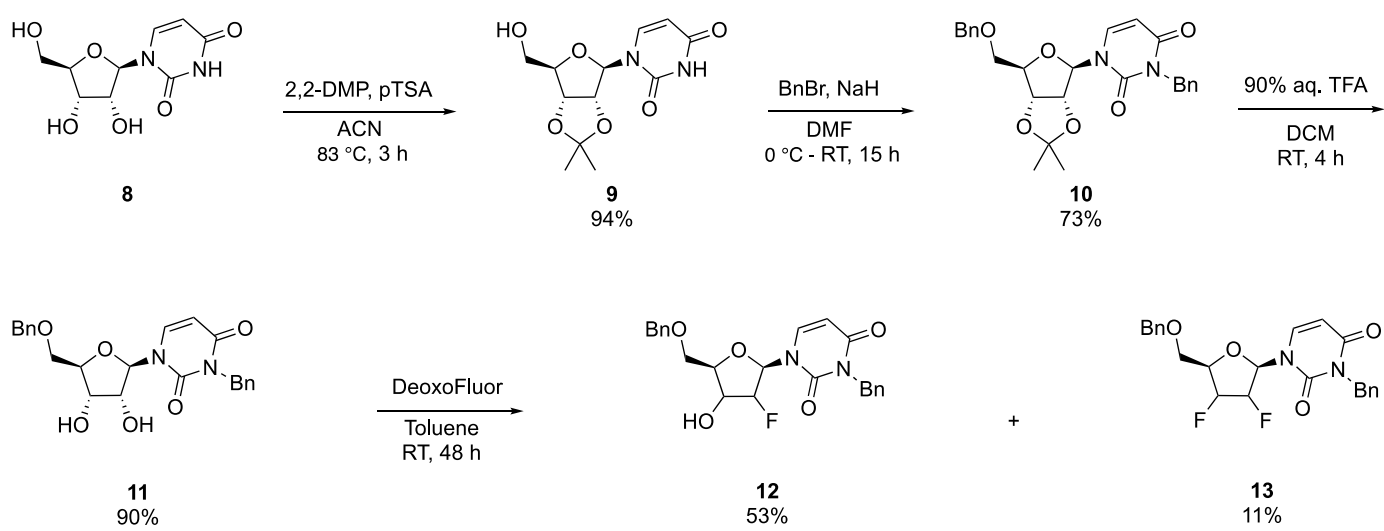

Scheme 2. Benzylation and fluorination reactions leading to compounds $\mathbf{1 2}$ and $\mathbf{1 3}$. Abbreviations are as following: 2,2-DMP: 2,2-dimethoxypropane; $\mathrm{ACN}$ : acetonitrile; $\mathrm{BnBr}$ : benzyl bromide; $\mathrm{NaH}$ : sodium hydride; TFA: trifluoroacetic acid, DCM: dichloromethane; DeoxoFluor: bis(2-methoxyethyl) aminosulfur trifluoride

\subsection{Conformational Analysis of the Synthesized Analogues}

The sugar moiety of the nucleosides is found with four different stereochemistries: ' $r i b o^{\prime}$, where the substituents on both $\mathrm{C} 2^{\prime}$ and $\mathrm{C}^{\prime}$ ' are in a 'down' configuration; ' $a r a^{\prime}$ ', where the $\mathrm{C} 2$ ' has the substituent 'up'; ' $x y l o^{\prime}$, where the $\mathrm{C} 2$ ' substituent is 'down' and the $3^{\prime}$ is 'up'; and 'lyxo', where both substituents are 'up' (Scheme S1A). Electronegative atoms at $\mathrm{C} 2^{\prime}$ are known to reduce the magnitude of $J_{\mathrm{H}^{\prime}-\mathrm{H} 2^{\prime}}$ and $J_{\mathrm{H}^{\prime}-\mathrm{H} 3^{\prime}}$ [35]. However, the $2^{\prime}$-fluoro- $\beta$-D-dideoxyuridine molecules are reported with a coupling constant of $3.3 \mathrm{~Hz}$ for $\mathrm{H}^{\prime}-\mathrm{H}^{\prime}{ }^{\prime}$ [36] and in general, $\mathrm{J}_{\mathrm{H} 1^{\prime}-\mathrm{H} 2^{\prime}}$ in $\beta$-nucleosides with a $2^{\prime}$-ara substituent is in the range of 3-4 Hz [37]. Barchi et al. [38] reported the synthesis and conformational analysis of the $2^{\prime}, 3^{\prime}$-dideoxy-2', $3^{\prime}$-difluoro uridine analogues with the ara- and xylo-stereochemistry (Table S1), and the general trend of the values of the coupling constants mentioned above are in agreement with McAtee et al. [37].

The absence of a $J_{\mathrm{H} 1^{\prime}-\mathrm{H} 2^{\prime}}$ coupling in the ${ }^{1} \mathrm{H}\{\mathrm{F}\} \mathrm{NMR}$ of $\mathbf{1 2}$ suggested that $\mathrm{F} 2^{\prime}$ was more likely to be pointing 'down' (xylo- or ribo-stereochemistry). However, not all the data in the literature seem to follow this general trend; the reason for this might be the tendency of nucleosides to exist in two distinct conformations: the so-called S-type (south, C2'-endo) and N-type (north, C3'-endo) conformation (Scheme S1B). It is reported that for each diastereomer, two potential conformers can be observed and experimental values of the $\mathrm{H}-\mathrm{H}$ and $\mathrm{F}-\mathrm{H}$ coupling constants would be influenced [35]. In order to verify the stereochemistry of the derived structures, we performed a further investigation and utilisation of the heteronuclear NOE experiments. This technique has made a significant contribution to the conformational analysis of nucleosides and it is very often utilised for fluorinated nucleosides [39-41]. Heteronuclear NOE experiments and Density-functional theory (DFT) calculations were then performed (B3LYP/6-31G* level of theory) to determine the relative stereochemistry at the $2^{\prime}$ - and $3^{\prime}$-positions of compound 12.

The eight conformers (the north and south conformer for each of the diastereomers $S R, R R, R S$ and SS) are shown in the SI (Figure S6). In Tables 1 and 2, the theoretically calculated values of the coupling constants $[42,43]$ and the distances of each proton of the sugar moiety from the fluorine are shown for each conformer. Comparison of those estimated values with the experimental data led to the conclusion that the $\mathrm{C} 1$ conformer ( $R S$-north) was the closest model to our observations, suggesting a retention of stereochemistry at $\mathrm{C} 2^{\prime}$ (C1, Tables 1 and 2). Furthermore, ring conformation 1 (north) is predicted to be more stable for all diastereomers apart from $\mathrm{D}(S S)$; in the case of $\mathrm{C}(R S)$, the energy difference is quite substantial. The ring is quite rigid and $\mathrm{C} 1$ will be the predominant conformer, so any conformational equilibrium can be neglected. Later, X-ray crystallography allowed for a complete stereochemical assignment (Figure 1) and confirmed the results of NMR analysis. 
Table 1. Spin-spin coupling constants (calculated and experimental values) for conformers A1-D2 of compound 12. Coupling constants are shown in $\mathrm{Hz}$. Experimental values were recorded in $\mathrm{CDCl}_{3}$.

\begin{tabular}{|c|c|c|c|c|c|c|c|}
\hline \multicolumn{8}{|c|}{ C1 (RS-north) } \\
\hline & Relative E (kJ/mol) & $J_{\mathrm{F}-\mathrm{H} 1^{\prime}}(\mathrm{Hz})$ & $J_{\mathrm{F}-\mathrm{H} 3^{\prime}}(\mathrm{Hz})$ & $J_{\mathrm{H} 1^{\prime}-\mathrm{H} 2^{\prime}}(\mathrm{Hz})$ & $J_{\mathrm{H}^{\prime}-\mathrm{H} 3^{\prime}}(\mathrm{Hz})$ & $J_{\mathrm{H}^{\prime}-\mathrm{H} 4^{\prime}}(\mathrm{Hz})$ & Avg. Deviation \\
\hline A1 (SR-north) & 0 & 3.7 & 18.0 & 7.2 & 6.3 & 8.6 & 4.48 \\
\hline A2 (SR-south) & 2.58 & 32.9 & 18.7 & 1.9 & 0.9 & 1.9 & 3.00 \\
\hline B1 (RR-north) & 0 & 20.0 & 39.9 & 0.8 & 3.4 & 8.6 & 6.21 \\
\hline B2 (RR-south) & 9.47 & 16.9 & 3.2 & 6.1 & 5.8 & 1.0 & 2.31 \\
\hline $\mathrm{C} 1$ (RS-north) & 0 & 22.8 & 17.7 & 0.8 & 1.2 & 3.2 & 1.68 \\
\hline C2 (RS-south) & 31.44 & 20.0 & 24.5 & 4.2 & 6.2 & 7.3 & 3.46 \\
\hline D1 (SS-north) & 9.83 & 6.2 & 3.5 & 7.2 & 6.4 & 2.7 & 3.77 \\
\hline D2 (SS-south) & 0 & 24.1 & 39.2 & 3.6 & 3.8 & 7.5 & 6.11 \\
\hline Experimental & & 21.2 & 9.6 & 0 & 0 & 2.8 & \\
\hline
\end{tabular}

Table 2. Calculated and experimental distance values for conformers A1-D2 of compound 12. Distances are shown in $\AA$. Experimental values were recorded in $\mathrm{CDCl}_{3}$.

\begin{tabular}{cccccc}
\hline & $\mathbf{d}\left(\mathbf{F}-\mathbf{H 2}^{\prime}\right)(\mathbf{(})$ & $\mathbf{d}\left(\mathbf{F}-\mathbf{H} \mathbf{4}^{\prime}\right)(\mathbf{(})$ & $\mathbf{d}\left(\mathbf{F}-\mathbf{H}^{\prime}\right)(\mathbf{(})$ & $\mathbf{d}\left(\mathbf{F}-\mathbf{H} 3^{\prime}\right)(\mathbf{A})$ & Avg. Deviation \\
\hline A1 (SR-north) & 2.017 & 4.150 & 3.025 & 2.511 & 0.541 \\
A2 (SR-south) & 2.038 & 4.006 & 3.300 & 2.496 & 0.534 \\
B1 (RR-north) & 2.028 & 2.757 & 2.452 & 3.292 & 0.289 \\
B2 (RR-south) & 2.025 & 4.292 & 2.497 & 2.917 & 0.554 \\
C1 (RS-north) & 2.036 & 2.630 & 2.419 & 2.511 & 0.048 \\
C2 (RS-south) & 2.025 & 4.313 & 2.462 & 2.417 & 0.536 \\
D1 (SS-north) & 2.014 & 4.076 & 3.108 & 2.951 & 0.552 \\
D2 (SS-south) & 2.017 & 4.046 & 3.285 & 3.288 & 0.618 \\
NOE & 1.000 & 0.174 & 0.437 & 0.330 & \\
Distance & 2.027 & 2.713 & 2.327 & 2.438 & \\
\hline
\end{tabular}

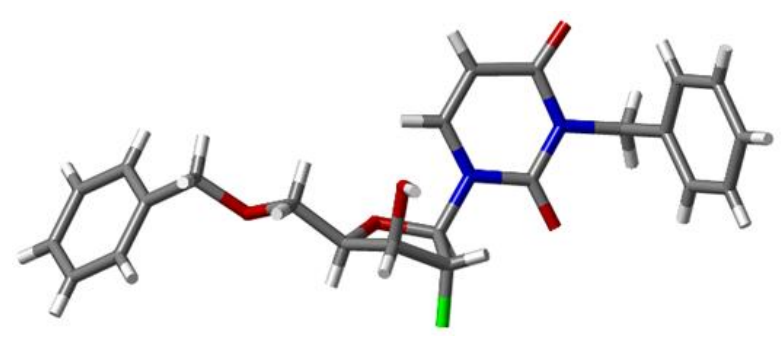

Figure 1. X-ray crystal structure of molecule 12.

Investigation of the stereochemistry of molecule $\mathbf{1 3}$ was then performed by a series of selective heteronuclear NOE experiments (HOESY). ${ }^{1} \mathrm{H},{ }^{19} \mathrm{~F}$ HMBC confirmed that the doublet at $-192 \mathrm{ppm}$ corresponds to F2' and the doublet at -208 ppm to F3' (SI, Figure S5). The selective HOESY allowed the determination of the stereochemistry. Selective irradiation of the F3' (Figure 2A) revealed a strong NOE with the $\mathrm{H}^{\prime}$ and $\mathrm{H}^{\prime \prime}$, which indicates that the $\mathrm{F}^{\prime}$ 'is in the $\beta$-face of the sugar. Selective irradiation of the F2' (Figure 2B) led to a strong NOE on the $\mathrm{H}^{\prime}$ ' and a weak NOE on the $\mathrm{H} 4^{\prime}$, which, combined with the previous experiments, suggests that the $\mathrm{F}^{\prime}$ is pointing in the opposite direction. 
A

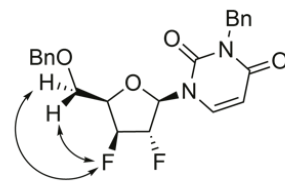

F3' selective irradiation
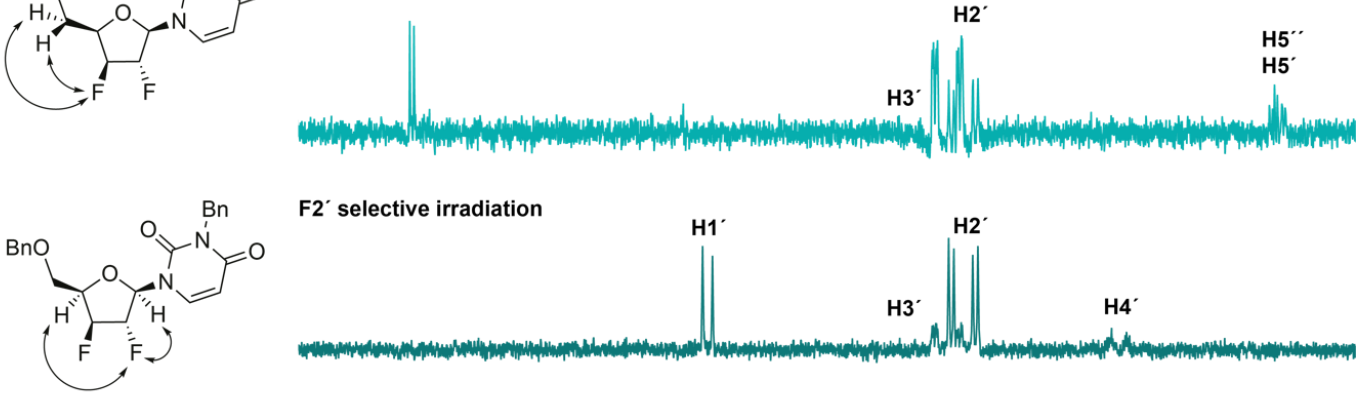

F2' selective irradiation

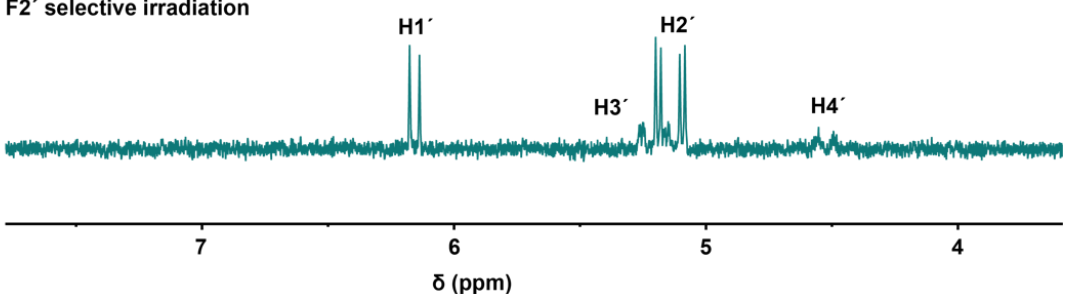

Figure 2. Heteronuclear NOE experiments (HOESY) for compound $13\left(282 \mathrm{MHz}, \mathrm{CDCl}_{3}\right)$. The mixing time of the experiment was $600 \mathrm{~ms}$. (A) Selective irradiation of the F3'. (B) Selective irradiation of the $\mathrm{F} 2^{\prime}$.

\subsection{Mechanistic Proposal: Neighbouring-Group Participation}

As suggested by the NOE and crystallographic data, the stereochemistry for compounds $\mathbf{1 2}$ and $\mathbf{1 3}$ is suggested to be $x y l o$. For a simpler system, such as an alcohol or diol, an inversion of the stereochemistry at $\mathrm{C}^{\prime}$ due to an $\mathrm{S}_{\mathrm{N}} 2$ mechanism would be expected. On the contrary, the retention of stereochemistry observed in this case could be contributed to the 'neighbouring-group participation', an established phenomenon with sugars and nucleosides. Indeed, the formation of anhydro nucleosides [44] such as 16 and 20 during DAST-type reactions has been previously reported [41,45,46], and an adapted mechanistic proposal is shown in Scheme 3. We propose that the benzyl- as an electron-donating group is postulated to have a significant impact on the mechanistic outcome of the chemical transformation.

We suggest that the reaction initially occurs with a nucleophilic attack of the ribose $\mathrm{O} 2{ }^{\prime}$ to the electrophilic sulphur of the Deoxo-Fluor reagent. Then, the lone pair of the oxygen of the uracil moiety attacks the $\mathrm{C}^{\prime}$ ' of the ribose, leading to the first inversion of stereochemistry; the excellent leaving group is removed and the anhydro nucleoside $\mathbf{1 6}$ is formed. The fluoride anion attacks the $\mathrm{C}^{\prime}$, and this second inversion leads to the fluorinated nucleoside with the retained stereochemistry. 




11

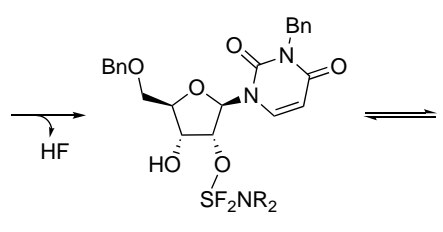

14

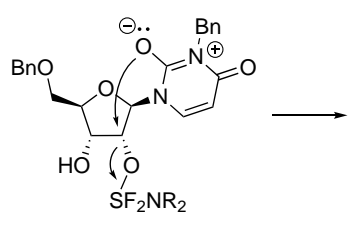

15





16

17

13

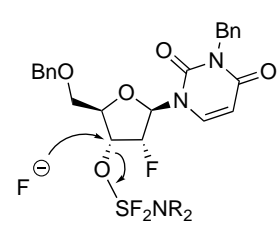

18<smiles>O=c1ccn(C2OC(COCc3ccccc3)C(OCCC(F)(F)F)C2F)c(=O)n1Cc1ccccc1</smiles>

17

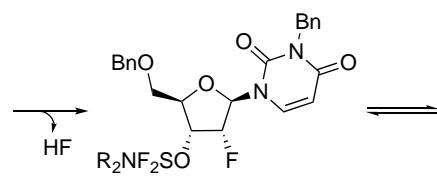

18



19

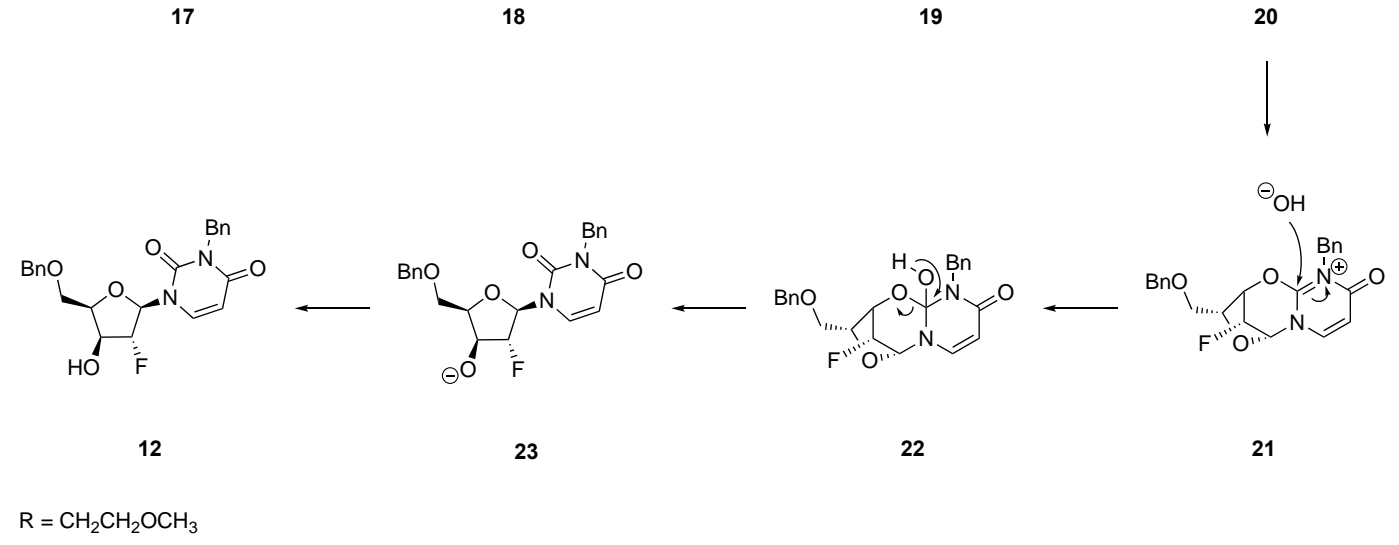

Scheme 3. Proposed mechanism leading to compounds 12 and 13.

\section{Discussion}

A method for the fluorination of $2^{\prime}$ and $3^{\prime}$ position of uridine derivatives has been developed, allowing for the structural and conformational analysis of these compounds. Nuclear Overhauser NMR techniques and X-ray crystallography have allowed the full structural and stereochemical assignment of the synthetic nucleoside analogues. The deoxy-fluorination reaction that allowed us to obtain our desired targets led to a retention of stereochemistry on the $\mathrm{C}^{\prime}$ and an inversion at $\mathrm{C}^{\prime}$, an interesting twist that yielded the xylo-derivatives. This twist can be attributed to neighbouring-group participation effects, common for uridine derivatives. This effect has been previously reported to contribute to the formation of anhydro nucleosides [41,44-46]. The relative stereochemistry of the F2' on the monofluorinated molecules was assigned by NOE spectroscopy as well as comparison of the theoretical and experimental values for $J_{\mathrm{F}-\mathrm{H} 1^{\prime}}$ and $J_{\mathrm{H} 1^{\prime}-\mathrm{H} 2^{\prime}}$. The final confirmation of the absolute stereochemistry 
was accomplished by X-ray crystallography. For the difluorinated analogues, HOESY spectroscopy gave us insight into examining the stereochemistry. Selective irradiation of the F2' revealed a weak $\mathrm{NOE}$ with $\mathrm{H}^{\prime}$ ' and a strong $\mathrm{NOE}$ with $\mathrm{H}^{\prime}{ }^{\prime}$, while irradiation of $\mathrm{F}^{\prime}$ revealed an $\mathrm{NOE}$ with $\mathrm{H}^{\prime}$ and $\mathrm{H}^{\prime \prime}$, which suggests that the compound has the $x y l o$-stereochemistry. We proposed that the mechanistic and conformational insight provided by this study can guide the further development of novel synthetic methods for the synthesis of the highly valuable, yet synthetically challenging fluorinated nucleosides.

\section{Materials and Methods}

\subsection{General Considerations}

All starting materials, reagents and solvents were commercially available and were used without further purification, unless otherwise stated. Chemical reagents and solvents were bought from Sigma Aldrich (Dorset, UK), Alfa Aesar (Cheshire, UK), Fisher (Loughborough, UK) or Fluorochem (Glossop, UK). Reactions were carried out under nitrogen or argon atmosphere in oven-dried glassware. When not specified, reactions were performed in clean, air-dried glassware. Fluorination reactions were carried out in oven-dried Teflon flasks. Thin layer chromatography (TLC) was performed using Machery Nagel (Dylan, Germany) polyester-backed sheets coated with silica (and fluorescent indicator UV254) to a thickness of $0.20 \mathrm{~mm}$. The reactions were monitored by TLC, and the plates were visualised under a UV lamp (254/365 nm, Mineralight model UVGL-58 lamp) and stained with potassium permanganate. Melting point was recorded using a Stuart SMP10 melting point apparatus and is uncorrected. NMR spectra of synthesised molecules were recorded at room temperature (RT) using Bruker Avance $500\left({ }^{1} \mathrm{H}\right.$ at $500 \mathrm{MHz},{ }^{13} \mathrm{C}$ at $126 \mathrm{MHz},{ }^{19} \mathrm{~F}$ at $\left.470 \mathrm{MHz}\right)$ and Bruker Avance $400\left({ }^{1} \mathrm{H}\right.$ at $400 \mathrm{MHz},{ }^{13} \mathrm{C}$ at $\left.101 \mathrm{MHz}\right)$ instruments, using deuterated solvents (Billerica, MA, USA). Chemical shifts, $\delta$, are reported in parts per million $(\mathrm{ppm})$ and are quoted relative to the centre of the reference nondeuterated solvent peak for $\delta_{\mathrm{H}}\left(\mathrm{CDCl}_{3}: 7.26 \mathrm{ppm} ; \mathrm{CD}_{3} \mathrm{OD}: 4.87,3.31 \mathrm{ppm}\right)$ and $\delta_{\mathrm{C}}\left(\mathrm{CDCl}_{3}\right.$ : 77.16 ppm; $\left.\mathrm{CD}_{3} \mathrm{OD}: 49.00 \mathrm{ppm}\right) .{ }^{13} \mathrm{C}$ NMR spectra were recorded with ${ }^{1} \mathrm{H}$ decoupling, while all spectra were processed and analysed using MestReNova 8.0.1 (Mestrelab Research, St. Louis, MO, USA). Coupling constants $J$ are given in hertz $(\mathrm{Hz})$. Multiplicity patterns are described as follows: bs-broad singlet, s-singlet, $\mathrm{t}$ - triplet, $\mathrm{tt}$ - triplet of triplets, ddd-doublet of doublets of doublets, ddt-doublet of doublets of triplets, $\mathrm{m}$-multiplet. One-dimensional ${ }^{1} \mathrm{H},{ }^{13} \mathrm{C}$ DEPTQ (distorsionless enhancement by polarization transfer including the detection of quaternary nuclei), ${ }^{19} \mathrm{~F}$ experiments as well as two-dimensional $\left[{ }^{1} \mathrm{H},{ }^{1} \mathrm{H}\right]$ DQFCOSY (double quantum filtered correlation spectroscopy), $\left[{ }^{1} \mathrm{H},{ }^{13} \mathrm{C}\right]$ HSQC (heteronuclear single quantum correlation spectroscopy), and $\left[{ }^{1} \mathrm{H},{ }^{13} \mathrm{C}\right] \mathrm{HMBC}$ (heteronuclear multiple bond correlation spectroscopy) experiments were utilised for structure determination.

\subsection{Preparation of $2^{\prime}, 3^{\prime}$-O-Isopropylidene Uridine (9)}

Uridine 8 (500 mg, $2 \mathrm{mmol}$ ) was dissolved in acetonitrile (30 mL). 2,2-dimethoxypropane ( $2 \mathrm{~mL}$, $16 \mathrm{mmol}$ ) and $p$-toluenesulfonic acid $(15 \mathrm{mg}$ ) were added and the mixture was refluxed for $3 \mathrm{~h}$. The reaction mixture was concentrated under vacuum to give a brown residue. The residue was purified by flash chromatography (100\% DCM to $100 \%$ acetone in a stepwise gradient) to give the desired compound 9. [47] (534 mg, 94\% yield). ${ }^{1} \mathrm{H}-\mathrm{NMR}\left(\mathrm{CD}_{3} \mathrm{OD}, 500 \mathrm{MHz}\right) \delta(\mathrm{ppm}) 7.86(\mathrm{~d}, \mathrm{~J}=8.1 \mathrm{~Hz}$, $1 \mathrm{H}), 5.89(\mathrm{~d}, J=3.0 \mathrm{~Hz}, 1 \mathrm{H}), 5.71(\mathrm{~d}, J=8.1 \mathrm{~Hz}, 1 \mathrm{H}), 4.93(\mathrm{dd}, J=6.6,3.2 \mathrm{~Hz}, 1 \mathrm{H}), 4.84(\mathrm{dd}, J=6.5$, $3.4 \mathrm{~Hz}, 1 \mathrm{H}), 4.23(\mathrm{~m}, 1 \mathrm{H}), 3.79(\mathrm{dd}, J=12.0,3.6 \mathrm{~Hz}, 1 \mathrm{H}), 3.73(\mathrm{dd}, J=12.2,3.8 \mathrm{~Hz}, 1 \mathrm{H}), 1.57(\mathrm{~s}, 3 \mathrm{H})$, 1.38 (s, 3H). ${ }^{13} \mathrm{C}-\mathrm{NMR}-\mathrm{DEPTQ}\left(\mathrm{CD}_{3} \mathrm{OD}, 126 \mathrm{MHz}\right) \delta$ (ppm) 164.8, 150.6, 142.4, 113.7, 101.2, 92.7, 86.9, 84.4, 80.8, 61.6, 26.1, 24.1. MS $\left(\mathrm{ES}^{+}\right) \mathrm{m} / z$ 285.1 $\left([\mathrm{M}+\mathrm{H}]^{+}, 100 \%\right), 569.2\left([2 \mathrm{M}+\mathrm{H}]^{+}, 67 \%\right), \mathrm{HRMS}_{\left(\mathrm{ES}^{+}\right)}$ $m / z$ calc. for $\mathrm{C}_{12} \mathrm{H}_{17} \mathrm{~N}_{2} \mathrm{O}_{6}[\mathrm{M}+\mathrm{H}]^{+} 285.1081$, found 285.1075 .

\subsection{Preparation of 3,5'-dibenzyl-2', $3^{\prime}$-O-Isopropylidene Uridine (10)}

$\mathrm{NaH}(60 \%$ dispersion in oil, $260 \mathrm{mg}, 14.1 \mathrm{mmol})$ was added into a stirred solution of $2^{\prime}, 3^{\prime}$-O-isopropylidene uridine 9 (1 g, $\left.3.52 \mathrm{mmol}\right)$ in dry DMF $(25 \mathrm{~mL})$ under argon atmosphere, 
and the mixture was cooled at $0{ }^{\circ} \mathrm{C}$ using an ice bath. $\mathrm{BnBr}(24.65 \mathrm{mmol}, 2.93 \mathrm{~mL})$ was added dropwise under argon atmosphere, with cooling and stirring. The reaction was monitored by TLC (hexane/acetone: $2 / 1$ ) and judged complete after $4 \mathrm{~h}$. The reaction mixture was quenched with $\mathrm{MeOH}$ $(25 \mathrm{~mL})$ and concentrated and coevaporated with toluene $(50 \mathrm{~mL})$. The crude material was purified by flash column chromatography (hexane/acetone: stepwise gradient) to give the desired product $10(1.2 \mathrm{~g}, 73 \%$ yield $)$ as a white solid. ${ }^{1} \mathrm{H} \mathrm{NMR}\left(\mathrm{CDCl}_{3}, 500 \mathrm{MHz}\right) \delta(\mathrm{ppm}) 7.52(\mathrm{~d}, J=8.1 \mathrm{~Hz}$, $1 \mathrm{H}), 7.46(\mathrm{apd}, J=7.3 \mathrm{~Hz}, 2 \mathrm{H}), 7.36-7.23(\mathrm{~m}, 8 \mathrm{H}), 5.93(\mathrm{~d}, J=2.6 \mathrm{~Hz}, 1 \mathrm{H}), 5.55(\mathrm{~d}, J=8.1 \mathrm{~Hz}, 1 \mathrm{H})$, $5.11(\mathrm{~d}, J=13.7 \mathrm{~Hz}, 1 \mathrm{H}), 5.02(\mathrm{~d}, J=13.8 \mathrm{~Hz}, 1 \mathrm{H}), 4.81(\mathrm{dd}, J=6.2,2.7 \mathrm{~Hz}, 1 \mathrm{H}), 4.73(\mathrm{dd}, J=6.2,2.6 \mathrm{~Hz}$, $1 \mathrm{H}), 4.54-4.48(\mathrm{~m}, 2 \mathrm{H}), 4.46-4.30(\mathrm{~m}, 1 \mathrm{H}), 3.76(\mathrm{dd}, J=10.6,2.5 \mathrm{~Hz}, 1 \mathrm{H}), 3.65(\mathrm{dd}, J=10.6,3.5 \mathrm{~Hz}, 1 \mathrm{H})$, $1.58(\mathrm{~s}, 3 \mathrm{H}), 1.35(\mathrm{~s}, 3 \mathrm{H}) .{ }^{13} \mathrm{C} \mathrm{NMR}\left(\mathrm{CDCl}_{3}, 126 \mathrm{MHz}\right) \delta(\mathrm{ppm}) 162.8,151.0,138.7,137.2,136.8,129.3$, 128.7, 128.5, 128.3, 128.0, 127.7, 114.1, 101.7, 93.6, 85.9, 85.6, 81.1, 73.9, 70.3, 44.2, 27.4, 25.5. MS (ES+) $\mathrm{m} / \mathrm{z}$ $465.2\left([\mathrm{M}+\mathrm{H}]^{+}, 100 \%\right), 946.4\left(\left[2 \mathrm{M}+\mathrm{NH}_{4}\right]^{+}, 49 \%\right), \mathrm{HRMS}\left(\mathrm{ES}^{+}\right)$calc. for $\mathrm{C}_{26} \mathrm{H}_{29} \mathrm{~N}_{2} \mathrm{O}_{6}[\mathrm{M}+\mathrm{H}]^{+} \mathrm{m} / \mathrm{z}$ 465.2020 , found 465.2007 .

\subsection{Preparation of 3,5'-Dibenzyl-uridine (11)}

Compound $10(1.1 \mathrm{~g}, 2.58 \mathrm{mmol})$ was added in a $1 / 1$ solution of $90 \%$ aqueous trifluoroacetic acid/DCM $(25 \mathrm{~mL})$ and the mixture was stirred for $4 \mathrm{~h}$ at RT. The reaction was monitored by TLC (hexane/acetone: $2 / 1$ ) and was stopped when it was judged complete. The mixture was concentrated under vacuum and coevaporated with toluene $(3 \times 50 \mathrm{~mL})$. The residue was purified by flash column chromatography (hexane/acetone, stepwise gradient) to give $\mathbf{1 1}$ as a white foam (983 $\mathrm{mg}, 90 \%$ yield). ${ }^{1} \mathrm{H}$ NMR $\left(\mathrm{CD}_{3} \mathrm{OD}, 400 \mathrm{MHz}\right) \delta(\mathrm{ppm}) 7.98(\mathrm{~d}, J=8.1 \mathrm{~Hz}, 1 \mathrm{H}), 7.38-7.36(\mathrm{~m}, 4 \mathrm{H}), 7.34-7.21(\mathrm{~m}, 6 \mathrm{H})$, $5.91(\mathrm{~d}, J=4.0 \mathrm{~Hz}, 1 \mathrm{H}), 5.41(\mathrm{~d}, J=8.1 \mathrm{~Hz}, 1 \mathrm{H}), 5.04(\mathrm{~s}, 2 \mathrm{H}), 4.61-4.53(\mathrm{~m}, 2 \mathrm{H}), 4.18(\mathrm{apt}, J=5.1 \mathrm{~Hz}$, $1 \mathrm{H}), 4.14-4.08(\mathrm{~m}, 2 \mathrm{H}), 3.87(\mathrm{dd}, J=10.9,2.4 \mathrm{~Hz}, 1 \mathrm{H}), 3.73(\mathrm{dd}, J=10.9,2.4 \mathrm{~Hz}, 1 \mathrm{H}) . \mathrm{MS}\left(\mathrm{ES}^{+}\right) \mathrm{m} / \mathrm{z}$ $425.2\left([\mathrm{M}+\mathrm{H}]^{+}, 100 \%\right), 442.2\left(\left[\mathrm{M}+\mathrm{NH}_{4}\right]^{+}, 53 \%\right), 849.3\left([2 \mathrm{M}+\mathrm{H}]^{+}, 20 \%\right), 866.4\left(\left[2 \mathrm{M}+\mathrm{NH}_{4}\right]^{+}, 5 \%\right)$, HRMS (ES ${ }^{+}$) calc. for $\mathrm{C}_{23} \mathrm{H}_{25} \mathrm{~N}_{2} \mathrm{O}_{6}[\mathrm{M}+\mathrm{H}]^{+} \mathrm{m} / z$ 425.1707, found 425.1704 .

\subsection{General Procedure for the Fluorination Reactions}

In a dry, clean Teflon flask, the nucleoside (50-100 mg, 1 eq.) was dissolved in dry solvent (4-10 mL, toluene). Under cooling at $-78{ }^{\circ} \mathrm{C}$, stirring and argon atmosphere, Deoxo-Fluor $(50 \%$ solution in THF) (10 eq.) was slowly added with a plastic syringe. The reaction was then left to stir at RT for an appropriate time, monitored by TLC. When complete, $3 \mathrm{~mL}$ of ethyl acetate were added. Then, $5 \mathrm{~mL}$ of calcium carbonate or sodium bicarbonate saturated solution were added dropwise. The reaction mixture was stirred at RT for $30 \mathrm{~min}$. Then, the mixture was transferred into a separating funnel and the organic layer was separated. The aqueous layer was washed with ethyl acetate $(5 \mathrm{~mL})$. The combined organic layers were dried over $\mathrm{MgSO}_{4}$, evaporated under vacuum and purified by flash column chromatography (hexane/ethyl acetate: stepwise gradient).

\subsubsection{1-(5-O-Benzyl-3-O-2'-deoxy-2'-fluoro- $\beta$-D-arabinofuranosyl)- $\mathrm{N}^{3}$-benzyluracil (12)}

Compound 12 was prepared ( $54 \mathrm{mg}, 53 \%$ yield) by following the general procedure described in Section 4.5 using compound $11(100 \mathrm{mg}, 0.23 \mathrm{mmol})$ and Deoxo-Fluor $(1 \mathrm{~mL}, 2.36 \mathrm{mmol})$ in toluene (4 mL). mp: $131-133^{\circ} \mathrm{C} .{ }^{1} \mathrm{H}$ NMR $\left(\mathrm{CDCl}_{3}, 500 \mathrm{MHz}\right) \delta(\mathrm{ppm}) 7.63(\mathrm{~d}, J=8.2 \mathrm{~Hz}, 1 \mathrm{H}), 7.48-7.44(\mathrm{~m}, 2 \mathrm{H})$, $7.40-7.27(\mathrm{~m}, 8 \mathrm{H}), 5.92(\mathrm{~d}, J=20.9 \mathrm{~Hz}, 1 \mathrm{H}), 5.63(\mathrm{~d}, J=8.1 \mathrm{~Hz}, 1 \mathrm{H}), 5.17-5.01(\mathrm{~m}, 2 \mathrm{H}), 4.98(\mathrm{~d}, J=48.8 \mathrm{~Hz}$, $1 \mathrm{H}), 4.61(\mathrm{aq}, J=11.5 \mathrm{~Hz}, 2 \mathrm{H}), 4.43(\mathrm{dd}, J=2.8,9.9 \mathrm{~Hz}, 1 \mathrm{H}), 4.31(\mathrm{td}, J=2.8 \mathrm{~Hz}, 1 \mathrm{H}), 4.11(\mathrm{dd}, J=11.1$, $3.5 \mathrm{~Hz}, 1 \mathrm{H}), 4.11(\mathrm{dd}, J=11.1,3.5 \mathrm{~Hz}, 1 \mathrm{H}) .{ }^{19} \mathrm{~F}\{\mathrm{H}\} \mathrm{NMR}\left(\mathrm{CDCl}_{3}, 282 \mathrm{MHz}\right) \delta(\mathrm{ppm})-185(\mathrm{~s}, 1 \mathrm{~F})$. ${ }^{19} \mathrm{~F}$ NMR $\left(\mathrm{CDCl}_{3}, 282 \mathrm{MHz}\right) \delta(\mathrm{ppm})-185(\mathrm{ddd}, J=48.8,20.9,9.9 \mathrm{~Hz}) .{ }^{13} \mathrm{C} \mathrm{NMR}\left(\mathrm{CDCl}_{3}, 126 \mathrm{MHz}\right)$ $\delta$ (ppm) 162.6, 151.1, 138.8, 136.6 (2), 129.3, 128.9, 128.7, 128.6, 128.1, 127.9, 101.9, 98.7 (d, J = $185.5 \mathrm{~Hz})$, $91.0(\mathrm{~d}, J=38.8 \mathrm{~Hz}), 80.8,74.8(\mathrm{~d}, J=27.4 \mathrm{~Hz}), 74.5,68.5,44.3 . \mathrm{MS}^{\left(\mathrm{ES}^{+}\right)} \mathrm{m} / \mathrm{z} 427.2\left([\mathrm{M}+\mathrm{H}]^{+}, 100 \%\right)$, $449.1\left([\mathrm{M}+\mathrm{Na}]^{+}, 26 \%\right), 875.3\left([2 \mathrm{M}+\mathrm{Na}]^{+}, 15 \%\right)$, HRMS $\left(\mathrm{ES}^{+}\right)$calc. for $\mathrm{C}_{23} \mathrm{H}_{24} \mathrm{~F}_{1} \mathrm{~N}_{2} \mathrm{O}_{5}[\mathrm{M}+\mathrm{H}]^{+} \mathrm{m} / \mathrm{z}$ 427.1664, found 427.1662 . 


\subsubsection{1-(5-O-Benzyl-3-O-2' ${ }^{\prime} 3^{\prime}$-dideoxy-2', $3^{\prime}$-difluoro- $\beta$-D-xylofuranosyl)- $\mathrm{N}^{3}$-benzyluracil (13)}

Compound 13 was prepared ( $11.5 \mathrm{mg}, 11 \%$ yield) by following the general procedure in Section 4.5 using compound $11(100 \mathrm{mg}, 0.23 \mathrm{mmol})$ and Deoxo-Fluor $(1 \mathrm{~mL}, 2.36 \mathrm{mmol})$ in toluene $(4 \mathrm{~mL})$. ${ }^{1} \mathrm{H}$ NMR $\left(\mathrm{CDCl}_{3}, 500 \mathrm{MHz}\right) \delta(\mathrm{ppm}) 7.51-7.45(\mathrm{~m}, 2 \mathrm{H}), 7.41-7.27(\mathrm{~m}, 9 \mathrm{H}), 6.13(\mathrm{~d}, J=19.5 \mathrm{~Hz}, 1 \mathrm{H})$, $5.73(\mathrm{~d}, J=8.2 \mathrm{~Hz}, 1 \mathrm{H}), 5.22(\mathrm{ddd}, J=48.7,7.5,2.5 \mathrm{~Hz}, 1 \mathrm{H}), 5.13(\mathrm{dd}, J=47.8,10.4 \mathrm{~Hz}, 1 \mathrm{H}), 5.12(\mathrm{~m}, 2 \mathrm{H})$, $4.7(\mathrm{~m}, 2 \mathrm{H}), 4.66-4.57(\mathrm{~m}, 2 \mathrm{H}), 3.89(\mathrm{dd}, J=10.2,5.8 \mathrm{~Hz}, 1 \mathrm{H}), 3.84(\mathrm{ddd}, J=10.2,5.9,1.6 \mathrm{~Hz}, 1 \mathrm{H})$. ${ }^{19} \mathrm{~F}\{\mathrm{H}\} \mathrm{NMR}\left(\mathrm{CDCl}_{3}, 282 \mathrm{MHz}\right) \delta(\mathrm{ppm})-192(\mathrm{~d}, J=14.3 \mathrm{~Hz}, 1 \mathrm{~F}),-208(\mathrm{~d}, J=14.3 \mathrm{~Hz}, 1 \mathrm{~F}) .{ }^{13} \mathrm{C}$ NMR $\left(\mathrm{CDCl}_{3}, 126 \mathrm{MHz}\right) \delta 162.5,151.0,137.3,137.0,136.6,129.3,128.8,128.6,128.3,120.0,127.9,102.5$, $96.0(\mathrm{dd}, J=187.0,31.4 \mathrm{~Hz}), 91.9(\mathrm{dd}, J=184.6,30.0 \mathrm{~Hz}), 89.4(\mathrm{~d}, J=37.4 \mathrm{~Hz}), 81.1(\mathrm{~d}, J=19.2 \mathrm{~Hz}), 73.9$, $65.8(\mathrm{~d}, J=8.5 \mathrm{~Hz}), 44.4 . \mathrm{MS}\left(\mathrm{ES}^{+}\right) \mathrm{m} / z 429.2\left([\mathrm{M}+\mathrm{H}]^{+}, 100 \%\right), 446.2\left(\left[\mathrm{M}+\mathrm{NH}_{4}\right]^{+}, 89 \%\right), 451.1\left([\mathrm{M}+\mathrm{Na}]^{+}\right.$, $51 \%) 467.1\left([\mathrm{M}+\mathrm{K}]^{+}, 19 \%\right), 879.9\left([2 \mathrm{M}+\mathrm{Na}]^{+}, 19 \%\right)$, HRMS $\left(\mathrm{ES}^{+}\right)$calc. for $\mathrm{C}_{23} \mathrm{H}_{23} \mathrm{~F}_{2} \mathrm{~N}_{2} \mathrm{O}_{4}[\mathrm{M}+\mathrm{H}]^{+}$ $\mathrm{m} / \mathrm{z} 429.1620$, found 429.1618 .

\subsection{Modelling of the Conformers of Compound $\mathbf{1 2}$}

Conformational flexibility of $\mathbf{1 2}$ was initially assessed by Monte Carlo MMFF conformational search. For each of the 4 stereoisomers, the 2 conformers (north and south) with the lowest relative energy were subjected to DFT geometry optimization in vacuum at the B3LYP/6-31G* level of theory. All calculations were performed using Spartan'18 (Version 1.1.4, Wavefunction, CA, USA) running on a Windows 10 computer equipped with a IntelCore i7 processor at $4 \mathrm{GHz}$ and $16 \mathrm{~GB}$ of memory.

\subsection{Heteronuclear NMR Spectroscopy}

All ${ }^{1} \mathrm{H},{ }^{19} \mathrm{~F}$ correlations were acquired using a Bruker AVIII HD 500 NMR instrument equipped with a room-temperature $5 \mathrm{~mm}$ BBFO+ probe (Billerica, MA, USA). The HMBC experiment was recorded using the standard Bruker pulse sequence hmqcgpqf that was altered by removing decoupling during acquisition and by adding ${ }^{1} \mathrm{H} /{ }^{19} \mathrm{~F}$ switches. HOESY experiments were obtained by following a protocol described elsewhere [48].

\subsection{X-Ray Crystallography}

Crystal Data for $\mathrm{C}_{23} \mathrm{H}_{23} \mathrm{~N}_{2} \mathrm{O}_{5} \mathrm{~F}(\mathrm{M}=426.44 \mathrm{~g} / \mathrm{mol})$ : monoclinic, space group $P 2_{1}$ (no. 4), $a=10.1992(16) \AA, b=9.3210(18) \AA, c=10.7915(16) \AA, \beta=92.241(7)^{\circ}, \mathrm{V}=1025.1(3) \AA^{3}, \mathrm{Z}=2$, $\mathrm{T}=125(2) \mathrm{K}, \mu(\mathrm{CuK} \alpha)=0.869 \mathrm{~mm}^{-1}$, Dcalc $=1.381 \mathrm{~g} / \mathrm{cm}^{3}, 11,755$ reflections measured, 3077 unique (Rint $=0.0404)$. The final R1 was $0.0314(\mathrm{I}>2 \sigma(\mathrm{I}))$ and $w R 2$ was 0.0816 (all data). Flack $-0.13(12)$. CCDC 2,027,460 contains the supplementary crystallographic data for this paper. These data can be obtained free of charge via http://www.ccdc.cam.ac.uk/conts/retrieving.html (or from the CCDC, 12 Union Road, Cambridge CB2 1EZ, UK; Fax: +44 1223 336033; E-mail: deposit@ccdc.cam.ac.uk).

Supplementary Materials: The following are available online. Scheme S1: The four different stereochemistries found in the sugar moiety of the nucleosides. Figure S1: Partial ${ }^{19} \mathrm{~F}\{\mathrm{H}\} \mathrm{NMR}$ (top) and ${ }^{19} \mathrm{~F} N \mathrm{NR}$ (bottom) of compound $12\left(282 \mathrm{MHz}, \mathrm{CDCl}_{3}\right.$ ). Figure S2: ${ }^{1} \mathrm{H}\{\mathrm{F}\} \mathrm{NMR}$ (top) and ${ }^{1} \mathrm{H} N \mathrm{NM}$ (bottom) of compound 12 $\left(500 \mathrm{MHz}, \mathrm{CDCl}_{3}\right)$. Figure S3: Partial ${ }^{19} \mathrm{~F}\{\mathrm{H}\} \mathrm{NMR}$ of compound $13\left(282 \mathrm{MHz}, \mathrm{CDCl}_{3}\right)$. Figure S4: ${ }^{1} \mathrm{H}$ NMR (top) and ${ }^{1} \mathrm{H}\{\mathrm{F}\} \mathrm{NMR}$ (bottom) of compound $13\left(500 \mathrm{MHz}, \mathrm{CDCl}_{3}\right)$. Figure S5: ${ }^{1} \mathrm{H}_{3}{ }^{19} \mathrm{~F} \mathrm{HMBC}$ of compound $13\left(\mathrm{CDCl}_{3}\right)$. Figure S6: Modelling of the conformers of compound 12 (B3LYP/6-31G* level of theory). Table S1: Experimental spin-spin coupling constant values for compounds S1 and S2. Figure S7: ${ }^{1} \mathrm{H}$ NMR (CD3OD, $500 \mathrm{MHz}$ ) of $2^{\prime}, 3^{\prime}-O$-isopropylidene uridine (9). Figure S8: ${ }^{13} \mathrm{C}$ NMR DEPTQ (CD3OD, $126 \mathrm{MHz}$ ) spectrum of 2',3'-O-isopropylidene uridine (9). Figure S9: HRMS of $2^{\prime}, 3^{\prime}-\mathrm{O}$-isopropylidene uridine (9). Figure $\mathrm{S} 10:{ }^{1} \mathrm{H} \mathrm{NMR}\left(\mathrm{CDCl}_{3}, 500 \mathrm{MHz}\right)$ of $3,5^{\prime}$-dibenzyl-2', $3^{\prime}-\mathrm{O}$-isopropylidene uridine (10). Figure S11: DEPT-Q NMR of 3,5'-dibenzyl-2', $3^{\prime}-\mathrm{O}$-isopropylidene uridine (10). Figure S12: HRMS of 3,5'-dibenzyl-2', $3^{\prime}$-O-isopropylidene uridine (10). Figure S13: ${ }^{1} \mathrm{H}-\mathrm{NMR}(\mathrm{CD} 3 \mathrm{OD}, 400 \mathrm{MHz})$


$126 \mathrm{MHz}$ ) of 1-(5-O-benzyl-3-O-2'-deoxy-2'-fluoro- $\beta$-D-arabinofuranosyl)- $N^{3}$-benzyluracil (12). Figure S16: HRMS of 1-(5-O-benzyl-3-O-2'-deoxy-2'-fluoro- $\beta$-D-arabinofuranosyl)- $N^{3}$-benzyluracil (12). Figure S17: ${ }^{13} \mathrm{C}$ NMR 
$\left(\mathrm{CDCl}_{3}, 126 \mathrm{MHz}\right)$ of 1-(5-O-benzyl-3-O-2', $3^{\prime}$-dideoxy-2', $3^{\prime}$-difluoro- $\beta$-D-xylofuranosyl)- $N^{3}$-benzyluracil (13). Figure S18: HRMS of 1-(5-O-benzyl-3-O-2 $2^{\prime}, 3^{\prime}$-dideoxy-2', $3^{\prime}$-difluoro- $\beta$-D-xylofuranosyl)- $N^{3}$-benzyluracil (13).

Author Contributions: Conceptualisation, F.M. and R.J.M.G; methodology, F.M. and T.L.; formal analysis, F.M., T.L. and A.M.Z.S.; investigation, F.M.; data curation, F.M., T.L. and A.M.Z.S.; writing-original draft preparation, F.M.; writing—review and editing, F.M.; T.L.; S.V.S.; A.M.Z.S.; M.J.B.B. and R.J.M.G.; visualisation, F.M. and T.L.; supervision, R.J.M.G.; project administration, R.J.M.G.; funding acquisition, R.J.M.G. All authors have read and agreed to the published version of the manuscript.

Funding: This work was supported by the EPSRC council (Grant number 1398501) and GlaxoSmithKline.

Acknowledgments: We thank the EPSRC UK National Mass Spectrometry Facility at Swansea University for mass spectrometric analyses.

Conflicts of Interest: The authors declare no conflict of interest.

\section{References}

1. Cavaliere, A.; Probst, C.K.; Westwell, D.A.; Slusarczyk, M. Fluorinated nucleosides as an important class of anticancer and antiviral agents. Future Med. Chem. 2017, 9, 809-1833. [CrossRef]

2. Shelton, J.; Lu, X.; Hollenbaugh, J.A.; Cho, J.H.; Amblard, F.; Schinazi, R.F. Metabolism, Biochemical Actions, and Chemical Synthesis of Anticancer Nucleosides, Nucleotides, and Base Analogs. Chem. Rev. 2016, 116, 14379-14455. [CrossRef] [PubMed]

3. Pankiewicz, K.W. Fluorinated Nucleosides. Carbohydr. Res. 2000, 327, 87-105. [CrossRef]

4. Ferraboschi, P.; Ciceri, S.; Grisenti, P. Synthesis of Antitumor Fluorinated Pyrimidine Nucleosides. Org. Prep. Proced. Int. 2017, 49, 69-154. [CrossRef]

5. Muller, K.; Faeh, C.; Diederich, F. Fluorine in pharmaceuticals: Looking beyond intuition. Science 2007, 317, 1881-1886. [CrossRef] [PubMed]

6. Han, J.; Remete, A.M.; Dobson, L.S.; Kiss, L.; Izawa, K.; Moriwaki, H.; Soloshonok, V.A.; O’Hagan, D. Next generation organofluorine containing blockbuster drugs. J. Fluor. Chem. 2020, 239, 109639. [CrossRef]

7. Inoue, M.; Sumii, Y.; Shibata, N. Contribution of Organofluorine Compounds to Pharmaceuticals. Acs Omega 2020, 5, 10633-10640. [CrossRef] [PubMed]

8. Brown, K.; Dixey, M.; Weymouth-Wilson, A.; Linclau, B. The synthesis of gemcitabine. Carbohydr. Res. 2014, 387, 59-73. [CrossRef]

9. Bartholome, A.; Janso, J.E.; Reilly, U.; O’Hagan, D. Fluorometabolite biosynthesis: Isotopically labelled glycerol incorporations into the antibiotic nucleocidin in Streptomyces calvus. Org. Biomol. Chem. 2016, 15, 61-64. [CrossRef] [PubMed]

10. Xu, X.H.; Yao, G.M.; Li, Y.M.; Lu, J.H.; Lin, C.J.; Wang, X.; Kong, C.H. 5-Fluorouracil Derivatives from the Sponge Phakellia fusca. J. Nat. Prod. 2003, 66, 285-288. [CrossRef]

11. Williams, R. Discontinued in 2013: Oncology drugs. Expert Opin. Investig. Drugs 2014, 24, 1-16. [CrossRef]

12. Infante, J.R.; Benhadji, K.A.; Dy, G.K.; Fetterly, G.; Ma, W.W.; Bendell, J.; Callies, S.; Adjei, A.A. Phase 1b study of the oral gemcitabine 'Pro-drug' LY2334737 in combination with capecitabine in patients with advanced solid tumors. Investig. New Drugs 2015, 33, 432-439. [CrossRef] [PubMed]

13. Blagden, S.P.; Rizzuto, I.; Suppiah, P.; O’Shea, D.; Patel, M.; Spiers, L.; Sukumaran, A.; Bharwani, N.; Rockall, A.; Gabra, H.; et al. Anti-tumour activity of a first-in-class agent NUC-1031 in patients with advanced cancer: Results of a phase I study. Br. J. Cancer 2018, 119, 815-822. [CrossRef] [PubMed]

14. Slusarczyk, M.; Lopez, M.H.; Balzarini, J.; Mason, M.; Jiang, W.G.; Blagden, S.; Thompson, E.; Ghazaly, E.; McGuigan, C. Application of ProTide technology to gemcitabine: A successful approach to overcome the key cancer resistance mechanisms leads to a new agent (NUC-1031) in clinical development. J. Med. Chem. 2014, 57, 1531-1542. [CrossRef] [PubMed]

15. A Targeted Anti-Cancer Therapy. Available online: https://www.rexahn.com/product-pipeline/rx-3117 (accessed on 16 November 2020).

16. Balboni, B.; El Hassouni, B.; Honeywell, R.J.; Sarkisjan, D.; Giovannetti, E.; Poore, J.; Heaton, C.; Peterson, C.; Benaim, E.; Lee, Y.B.; et al. RX-3117 (fluorocyclopentenyl cytosine): A novel specific antimetabolite for selective cancer treatment. Expert Opin. Investig. Drugs 2019, 28, 311-322. [CrossRef] [PubMed]

17. O’Hagan, D. Understanding organofluorine chemistry. An introduction to the C-F bond. Chem. Soc. Rev. 2008, 37, 308-319. [CrossRef] 
18. Withers, S.G.; Street, I.P.; Percival, M.D. Fluorinated Carbohydrates as Probes of Enzyme Specificity and Mechanism. In Fluorinated Carbohydrates; ACS Publications: Washington, DC, USA, 1988; pp. 59-77. [CrossRef]

19. Walsh, C. Fluorinated substrate analogs: Routes of metabolism and selective toxicity. Adv. Enzym. Relat. Areas Mol. Biol. 1983, 55, 197-289.

20. Ferraris, D.; Duvall, B.; Delahanty, G.; Mistry, B.; Alt, J.; Rojas, C.; Rowbottom, C.; Sanders, K.; Schuck, E.; Huang, K.C.; et al. Design, synthesis, and pharmacological evaluation of fluorinated tetrahydrouridine derivatives as inhibitors of cytidine deaminase. J. Med. Chem. 2014, 57, 2582-2588. [CrossRef]

21. Gillis, E.P.; Eastman, K.J.; Hill, M.D.; Donnelly, D.J.; Meanwell, N.A. Applications of Fluorine in Medicinal Chemistry. J. Med. Chem. 2015, 58, 8315-8359. [CrossRef]

22. Bohm, H.J.; Banner, D.; Bendels, S.; Kansy, M.; Kuhn, B.; Muller, K.; Obst-Sander, U.; Stahl, M. Fluorine in medicinal chemistry. Chembiochem 2004, 5, 637-643. [CrossRef]

23. Qiu, X.-L.; Xu, X.-H.; Qing, F.-L. Recent advances in the synthesis of fluorinated nucleosides. Tetrahedron 2010, 66, 789-843. [CrossRef]

24. De Clercq, E. Highlights in antiviral drug research: Antivirals at the horizon. Med. Res. Rev. 2013, 33, 1215-1248. [CrossRef] [PubMed]

25. Yates, M.K.; Seley-Radtke, K.L. The evolution of antiviral nucleoside analogues: A review for chemists and non-chemists. Part II: Complex modifications to the nucleoside scaffold. Antivir. Res 2019, 162, 5-21. [CrossRef] [PubMed]

26. Galmarini, C.M.; Mackey, J.R.; Dumontet, C. Nucleoside analogues and nucleobases in cancer treatment. Lancet Oncol. 2002, 3, 415-424. [CrossRef]

27. Jordheim, L.P.; Durantel, D.; Zoulim, F.; Dumontet, C. Advances in the development of nucleoside and nucleotide analogues for cancer and viral diseases. Nat. Rev. Drug Discov. 2013, 12, 447-464. [CrossRef] [PubMed]

28. Meanwell, M.; Silverman, S.M.; Lehmann, J.; Adluri, B.; Wang, Y.; Cohen, R.; Campeau, L.C.; Britton, R. A short de novo synthesis of nucleoside analogs. Science 2020, 369, 725-730. [CrossRef] [PubMed]

29. Pankiewicz, K.W.; Watanabe, K.A. Synthesis of 2 '- $\beta$-fluoro-substituted nucleosides by a direct approach. J. Fluor. Chem. 1993, 64, 15-36. [CrossRef]

30. Takamatsu, S.; Maruyama, T.; Katayama, S.; Hirose, N.; Naito, M.; Izawa, K.J. Synthesis of 9-(2,3-Dideoxy-2-fluoro- $\beta$-D-threo-pentofuranosyl)adenine (FddA) via a Purine 3'-Deoxynucleoside. J. Org. Chem. 2001, 66, 7469-7477. [CrossRef]

31. Srivastav, N.C.; Shakya, N.; Mak, M.; Liang, C.; Tyrrell, D.L.; Agrawal, B.; Kumar, R. Synthesis and in vitro antiviral activities of $3^{\prime}$-fluoro (or chloro) and 2', $3^{\prime}$-difluoro $2^{\prime}, 3^{\prime}$-dideoxynucleoside analogs against hepatitis B and C viruses. Bioorg. Med. Chem. 2010, 18, 7542-7547. [CrossRef]

32. Kim, K.R.; Moon, H.R.; Park, A.Y.; Chun, M.W.; Jeong, L.S. Design, synthesis, and biological evaluation of novel iso-D-2',3'-dideoxy-3'-fluorothianucleoside derivatives. Bioorg. Med. Chem. 2007, 15, 227-234. [CrossRef] [PubMed]

33. Snyder, N.L.; Seeberger, P.H.; Mukosera, G.T.; Held, E.M.K. 9.05 Technology-Enabled Synthesis of Carbohydrates. In Comprehensive Organic Synthesis II; Elsevier: Amsterdam, The Netherlands, 2014; pp. 111-142. [CrossRef]

34. Ragab, A.E.; Gruschow, S.; Tromans, D.R.; Goss, R.J. Biogenesis of the unique 4',5'-dehydronucleoside of the uridyl peptide antibiotic pacidamycin. J. Am. Chem. Soc. 2011, 133, 15288-15291. [CrossRef] [PubMed]

35. Erande, N.; Gunjal, A.D.; Fernandes, M.; Gonnade, R.; Kumar, V.A. Synthesis and structural studies of S-type/N-type-locked/frozen nucleoside analogues and their incorporation in RNA-selective, nuclease resistant 2'-5' linked oligonucleotides. Org. Biomol. Chem. 2013, 11, 746-757. [CrossRef] [PubMed]

36. Plavec, J.; Tong, W.; Chattopadhyaya, J. How Do the Gauche and Anomeric Effects Drive the Pseudorotational Equilibrium of the Pentofuranose Moiety of Nucleosides? J. Am. Chem. Soc. 1993, 115, 9734-9746. [CrossRef]

37. Michalik, M.; Hein, M.; Frank, M. NMR spectra of fluorinated carbohydrates. Carbohydr. Res. 2000, 327, 185-218. [CrossRef]

38. Barchi, J.J.; Karki, R.G.; Nicklaus, M.C.; Siddiqui, M.A.; George, C.; Mikhailopulo, I.A.E. Marquez, V.E. Comprehensive Structural Studies of 2',3'-Difluorinated Nucleosides: Comparison of Theory, Solution, and Solid State. J. Am. Chem. Soc. 2008, 130, 9048-9057. [CrossRef] [PubMed] 
39. Martinez-Montero, S.; Deleavey, G.F.; Kulkarni, A.; Martin-Pintado, N.; Lindovska, P.; Thomson, M.; Gonzalez, C.; Gotte, M.; Damha, M.J. Rigid 2',4'-difluororibonucleosides: Synthesis, conformational analysis, and incorporation into nascent RNA by HCV polymerase. J. Org. Chem. 2014, 79, 5627-5635. [CrossRef]

40. Martinez-Montero, S.; Deleavey, G.F.; Dierker-Viik, A.; Lindovska, P.; Ilina, T.; Portella, G.; Orozco, M.; Parniak, M.A.; Gonzalez, C.; Damha, M.J. Synthesis and properties of 2'-deoxy-2',4'-difluoroarabinose-modified nucleic acids. J. Org. Chem. 2015, 80, 3083-3091. [CrossRef]

41. Gosselin, G.; Puech, F.; Génu-Dellac, C.; Imbach, J.L. 1,2-Di-O-acetyl-5-O-benzoyl-3-deoxy-\%fluoro-Dxylofuranose. A versatile precursor for the synthesis of \%deoxy-3-fluoro-P-mxylofuranosyl nucleosides as potential antiviral agents. Carbohydr. Res. 1993, 249, 1-17. [CrossRef]

42. Haasnoot, C.; De Leeuw, F.; Altona, C. The relationship between proton-proton NMR coupling constants and substituent electronegativities-I: An empirical generalization of the Karplus equation. Tetrahedron 1980, 36, 2783-2792. [CrossRef]

43. Thibaudeau, C.; Plavec, J.; Chattopadhyaya, J. A New Generalized Karplus-type Equation Relating Vicinal Proton-Fluorine Coupling Constants to H-C-C-F Torsion Angles. J. Org. Chem. 1998, 63, 4967-4984. [CrossRef]

44. Szlenkier, M.; Boryski, J. Application of Sugar-Base Anhydro Bridge for Modification of Nucleosides in the 2'- and/or 3'-Positions-Revisited. Curr. Org. Chem. 2019, 23, 409-438. [CrossRef]

45. Jeonga, L.S.; Nicklausa, M.C.; George, C.; Marquez, V.E. Facile fluorination of deoxy-4'-thiopyrimidine nucleosides with "down" hydroxyl groups. Retention of configuration after fluoride opening of the quaternized N3-MEM anhydronucleosides. Tetrahedron Lett. 1994, 35, 7573-7576. [CrossRef]

46. Agyei-aye, K.; Yan, S.; Hebbler, A.K.; Baker, D.C. Preparation of 2,3'-Anhydropyrimidine Nucleosides using N,N-Diethylaminosulfur Trifluoride (DAST). Nucleosides Nucleotides 1989, 8, 327-337. [CrossRef]

47. Jones, G.H.; Taniguchi, M.; Tegg, D.; Moffatt, J.G. 4'-Substituted nucleosides. 5. Hydroxymethylation of nucleoside 5'-aldehydes. J. Org. Chem. 1979, 44, 1309-1317. [CrossRef]

48. Combettes, L.E.; Clausen-Thue, P.; King, M.A.; Odell, B.; Thompson, A.L.; Gouverneur, V.; Claridge, T.D. Conformational analysis of fluorinated pyrrolidines using 19F-1H scalar couplings and heteronuclear NOEs. Chemistry 2012, 18, 13133-13141. [CrossRef]

Sample Availability: Not available.

Publisher's Note: MDPI stays neutral with regard to jurisdictional claims in published maps and institutional affiliations.

(C) 2020 by the authors. Licensee MDPI, Basel, Switzerland. This article is an open access article distributed under the terms and conditions of the Creative Commons Attribution (CC BY) license (http://creativecommons.org/licenses/by/4.0/). 